\title{
Domestic Politics, Foreign Policy, and International Organization: The Case of Indonesia's Withdrawal from the United Nations
}

\author{
Yohanes Sulaiman \\ ysulaiman@gmail.com
}

\section{Dosen Jurusan Hubungan Internasional FISIP Universitas Jenderal Achmad Yani}

\begin{abstract}
Under what condition states will withdraw from an international organization? This article examines this question from the perspective of three systemic approaches: realism, liberalism, and constructivism by generating hypotheses from each approach and testing them on the case of Indonesia"s withdrawal from the United Nations in 1965. The systemic perspectives, however, could only provide partial answers to this puzzle, and thus the need to include domestic political analysis in conjunction of the systemic analysis in order to fully answer the question.
\end{abstract}

Key Words: Domestic Politics, Foreign Policy, International Organization

\section{Introduction}

Under what condition states will withdraw from an international organization? While there are abundant literature on cooperation between states, why states decide to build international institutions, and tout the benefits of regimes in international relations, there are very few discussions on when state will withdraw from international regimes, because in general, the withdrawal itself is seen as unthinkable. Take the example of "Brexit," the decision by the British voters in a referendum to leave the European Union, which caught the political and business elite all over the world off guard, was often characterized as "unthinkable." It is "unthinkable" that anyone would leave an international organization, due to economic and other benefits that the international organization, in this case, the European Union, provided, and the uncertainties that will result (The Economist: 2016). 
Yet, as "Brexit" shows, states do leave international organizations. This paper is trying to answer a puzzle in international organization theory: under what condition state thinks that international regimes no longer fit its interests and thus it will withdraw from international organization? In order to do so, it will be instructive to discuss the withdrawal of Indonesia from the United Nations.

The United Nations is an organization that emerges from the ashes of the Second World War with main purpose of maintaining global security and peace. By fostering cooperation in many aspects between nations, it is hoped that such cooperation will create more trust among nations, and that, in turn, lead to peace. Since major strands of the field of international relations basically in agreement that state is security maximizer and the United Nations itself as an entity is beneficial for national interest (Morgenthau: 1965), then withdrawing from the United Nations is supposedly unthinkable since the withdrawal will increase the insecurity especially for that particular state, not to mention giving up many benefits from being in the United Nations itself. Yet in January 1965 Indonesia decided to withdraw from the United Nations.

In order to answer this puzzle, first I will discuss some of the literatures from realism, institutionalism, and constructivism that deal with international organizations as my basic assumptions of the nature of international institutions. From these basic assumptions I will generate hypothesis that under what condition state will withdraw from international regimes. Second, I will test the hypotheses in case studies on Indonesia's withdrawal from the UN. Thirdly, I will evaluate the hypotheses of these perspectives and from the evaluation I will try to generate a new model that will try to fill the gap in the literature.

\section{Literature}

The debate in international relations regarding the necessity of international regimes is overall settled, as all sides in the debates essentially 
agree that international organizations do matters, important, and desirable, although each side has its own distinct argument. Neorealists such as Stephen Krasner argues that international regimes help hegemonic state to regulate the international system for its own advantages, while for smaller states, international regimes is also economically and politically beneficial as by joining international regimes smaller states are receiving the collective goods provided by the hegemon (Krasner, 1976).

Institutionalists such as Robert Keohane argues that international regimes are important for states in order to facilitate cooperation by reducing transaction costs that states have to pay in signing into agreements through providing information and rules that reduce incentives to cheat (Keohane: 1984). In fact, the function of regimes as information providers to its members is its most important function, since by fully informing member states, regimes will reduce uncertainties and thus reducing the risk of the state of engaging in potentially costly agreements (Hopf, 1998: 23) Since states can engage in mutually beneficial agreements with others without facing the risk of being deceived, then states will keep pursuing policy of cooperation.

Constructivists discuss international regimes through the lens of identity. Hopf argues that the distribution of identities and interests of the states determine states' willingness to cooperate. The reason is that identity subsumes reputation and identity can provide states necessary diagnostic information about what actions other states will take and thus providing some certainties in anarchical situation (Hopf: 1998: 189). As the result of the shared identity then states might see themselves as partners in pursuit of common interests and willing to cooperate. An example of this approach is Finnemore's arguments that international regimes can help spreading norms by persuading states to adopt beneficial changes through mutually beneficial interactions: for the stronger states, international organization can help spreading their values (norms) of scientific community to weaker state (in Finnemore's example: a 
Marshall Plan for ideas) while for weaker states, adapting the norm can help them emulate into strong and modern scientific state (science as a national pursuit), (Finnemore: 1993: 566). Thus international organization is enabling states to share each other identity and strengthen the bonds between states.

When we look further beyond these arguments, we can find some important commonalities between these perspectives, which lie on their assumptions of the main purposes of international regime. Some of the most important functions of international organizations (regimes) are to provide publik goods such as economic benefits (trade organizations) and to help reducing uncertainties in the anarchical world system by minimizing the possibilities of cheating by using rules that have to be observed by states and by providing better information. Yet, these approaches take different paths in their predictions on when the regime finally collapses or when states finally decide to abandon the international regime.

Neorealists, such as John Mearsheimer by assuming that international organization is as a function of great powers, argues that international (Mearsheime, 2000: 339) organization will collapse once it no longer suits the existing balance of power and when the hegemon that provides the security guarantee among member states withdraw (Mearsheime, 2000:45). While Mearsheimer assumes that institutions will simply disappear, Krasner injects the "stickiness of institution" variable, where he argues that regimes will remain until a critical event forces states to finally dismantle the regime (Krasneg, 1976:341). Joseph M. Grieco (1983: 184), working from the statelevel analysis, proposes that state will leave international organization (cooperative arrangement) when it realizes that other states can have greater gains from the cooperation and potentially able to even surpass the state. From all these realists' perspectives, then we can create a realist's hypothesis, which is state will withdraw from international organization once it believes the organization no longer suit its interests and even compromising its power 
relationship vis-à-vis other states and only a withdrawal by an important hegemon (great power) from the organization that can cause the collapse of the international organization.

Neoliberals/functionalists such as Keohane on the other hand argues that regimes will not be dismantled simply because state no longer believe the international organization can suit its interests or when the hegemon no longer able to prop the regimes (due to decline). The basis for this argument is that setting up a new regime is very expensive, due to high transaction costs and uncertainties in interactions between states (the sunk cost in creating the regime), (Keohane, 1984:100). Since the old regime has already been able to reduce the transaction cost and uncertainties in the first place, then abandoning it means state has to pay those high costs again if the state want to set up a new one to replace the old regime. As the result, instead of abandoning existing regimes, states will try to modify the existing regimes in order to suit the present need and thus in Keohane's words, "regimes tend to evolve rather than to die" and sympathized governments will have every incentive to maintain the regimes regardless the cost to their self-interests.

However, Keohane's argument is also problematic when we see that states do withdraw and abandon international organizations. There are cases where international organizations are simply abandoned by states such as the League of Nations, where the organization was simply abandoned after the outbreak of the Second World War, until it was replaced later by the United Nations. Shanks et al. try to answer this puzzle using the combination of functionalist-organizational ecology argument argue that states may withdraw from international institutions when they find the cost of maintaining the membership in the international institution is too high to bear, and thus states have to streamline their membership in international organization (e.g. by withdrawing from organizations which functions can be served by other larger (worldwide compared to regional) and established organizations (Shank et. al. 
2001: 168). So, Shanks et al.' argument is essentially the other side of Keohane's coin, that governments who have no sympathize toward the current regime will have no incentives to maintain it, especially when they see international regimes are not helping them in reducing their transaction costs (e.g. due to defections). Still, Shanks et al. add another caveat to the functionalist argument using the organizational ecology that generalized organizations will have higher rate of survival due to its flexibility, as they will be able to adapt to new demands.

From these perspectives then we can generate our neoliberal/ functionalist hypothesis that a state' position toward international regimes is based on how beneficial the regimes are toward reducing the state's transaction costs and how flexible the regimes are. If a state finds the international regimes non-beneficial, then the state will try to reform the regime if the state still shares common interests with the regime and if the regimes themselves are flexible enough that allow changes to take place. Otherwise, the state will abandon international regimes.

Constructivists see international regimes as a part of identity building, as international regimes help enabling states to understand each other as partners in common enterprise. As the result, institution will persist due to the shared identity among states concerned with this institution (Hopf, 1998: 191). Stretching this argument further, then we can also argue that state will not have much incentives to cooperate with other states, whom the state find no common identity since the uncertainties are too high a cost for the state to bear. From this argument then we can deduce the constructivist hypothesis that states will not join (or will leave) international institution if states do not think that it can find neither common identity nor the desire to build a common identity in the international institution.

Having discussed these literatures, then we can proceed to test these hypotheses into our case study, which is Indonesia's withdrawal from the 
United Nations in 1965. Since all these hypotheses are "systemic level types," this case study would not take domestic policy into consideration until the second part when I would build a new model that account for domestic policy.

\section{Case Study: Indonesia: "The Year of Living Dangerously" (1963-5)}

On the New Year Eve 1965, President Sukarno announced Indonesia's withdrawal from the United Nations. This action is very surprising, considering that this is the only case in the history of the United Nations that a state completely withdrew from that organization. In his announcement on Indonesia's withdrawal from the United Nations, Sukarno attributed his decision to his displeasure that Malaysia was about to take a seat on the United Nations Security Council (Mackie, 1974: 279).

Sukarno's animosity toward Malaysia, especially its prime minister, Tunku Abdul Rahman, was dated from 1958, when then-Malaya was believed to support separatist rebellions in Indonesia, notably the PRRI/Permesta (Legge, 1984: 363). In addition, Sukarno himself thought very lowly on Malaysia, claiming that Malaysia was never independent, but a puppet of the British in order to spread the British influence in Southeast Asia (Subritzky, 2000: 42). However, when the idea of Malaysia was flouted in 1961, Indonesia did not raise any objection due to its preoccupation with the issue of West Irian, as Indonesia at that time was embroiled in military and diplomatic "war" with the Dutch (Mackie, 1974: 103).

Things started to change by the end of 1962, when Indonesia was finally able to settle the question of West Irian. The year would be uneventful for the relationship between Indonesia and Malaysia, had there not been a rebellion in Brunei against the incorporation of Northern Kalimantan states (Brunei, Sabah, and Sarawak) to the Federation of Malaysia on December 8, 1962. While the revolt was quickly suppressed, Indonesia pointed at this as an evidence of the unwillingness of people of North Kalimantan to be 
incorporated into the British puppet state of Malaysia. Ill-chosen statements from Kuala Lumpur that blamed Jakarta that followed this rebellion further exacerbated the situations, as it stroked the nationalistic fervor that culminated on January 20, 1963, with Subandrio, Indonesian Foreign Minister, declared the policy of "Konfrontasi" against Malaysia, where Indonesia would "confront" Malaysia militarily and diplomatically.

At this point, however, Indonesia's economy was in shambles. Its policy of "regain West Irian" was very costly and thus it needed a face-saving arrangement to cease the policy of Konfrontasi. On 31 May and 1 June 1963, Sukarno met privately with the Tunku in Tokyo and they ended up issuing a joint communiqué stating that both governments would "refrain from making acrimonious attacks and disparaging references to each other" - thus ending Konfrontasi, and would resolve their differences "in a spirit of friendliness and goodwill." Apparently, Sukarno was friendly with the Tunku and resigned to the establishment of the federation. The Tunku was so pleased that he felt Sukarno "had clearly called off his confrontation without having had to be given anything in return (Jones, 2002: 157).

What was needed at this point was a face-saving formula that would allow Sukarno to call off confrontation and a plebiscite would be a good way to do so. Moreover, Indonesia was convinced that the people of Northern Kalimantan were actually unwilling to join the Malaysian Federation, as evident in the Brunei Rebellion. Thus, by pushing the issue of selfdetermination, Indonesia hoped that it could force both the British and the Malaya to give it a significant concession, or at least a face-saving arrangement, to cease the policy of confrontation (Mackie, 1974: 156). In order to do that, on June 11, 1963, the foreign ministers of Indonesia, Malaya, and the Philippines met in Manila to hammer the details and later, Sukarno, Tunku, and the Philippines President Diosdado Macapagal met in the Manila Summit that would take place from July 30 to August 5, 1963, to ratify it. 
The British, however, were desperate to leave Southeast Asia as it was very costly for the British to maintain Malaysiae"s security, especially in light of sluggish British economy (Subritzky, 2000: 62). As a result, they kept insisting the formation of the Malaysian Federation. On July 9, 1963, the Malaysia Agreement was signed in London, which created a federation including Malaya, Singapore, North Borneo, and Sarawak (Jones, 2002: 165). Ironically, Brunei was not included in the federation due to Bruneiees insistence on maintaining control over Brunei's oil revenues in return for paying a mere US\$40 million to the Malaysian Federal treasury (Mackie, 1974: 142)

Sukarno was enraged by the London agreement but he still decided to attend the Manila Summit, on July 30, 1963. More importantly for him was the fact that Indonesia"s proposal of having the United Nations Secretary General ascertain publik opinion in Sabah and Sarawak through an inquiry was accepted (Jones, 1971: 280) Things apparently could be settled peacefully.

While the summit indeed ended in what the US Ambassador Howard Jones saw as an Indonesian diplomatic triumph, as the ascertainment would be held and completed by September 14, the British were not in a mood for cooperation. On August 1, during the Manila Summit, the British Charge d'Affaires called Tunku, insisting to both Tunku and the Australian Prime Minister Mackenzie that August 31 was unalterable as the date for the Malaysian Federation (Mackie, 1974: 158). The UN Secretary General U Thant himself, who would be responsible for the inquiry, was not satisfied. He believed that he was only given a short time and with the Tunku's announcement that Malaysia would be proclaimed on September 16, he complained that the British implied that they were going to set up Malaysia regardless of the UN findings (Easter, 2004: 60, 2002: 188).

Therefore, when U Thant finally issued his findings on September 14 that "the wishes of a sizeable majority of the peoples of these territories to join in the Federation of Malaysia," and added his mild criticisms towards the 
British conduct, (Mackie, 1974: 176) Indonesia was not in the mood to acquiesce. On the morning of September 15, Howard Jones met an agitated Sukarno who declared that he could not accept the result of the ascertainment process, arguing that "certain procedures" were not carried out and accusing the British of playing the game that the Dutch played in Irian Barat (Jones, 2002: 195) Sukarno in his memoir further declared:

Setting another arbitrary date two weeks later despite the fact that the poll was not completed showed Britain's utter disregard of the outcome of this puppet survey.... I was infuriated. The Indonesian government had been tricked and made to look like a dummy. The subsequent demonstrations of enmity happened because of our bitter sense of betrayal.... This highhanded announcement, made while the ascertainment of the people's wishes was only in the opening stages, is ludicrous. Britain never even awaited the outcome of the U.N. assessment. I state that under the nose of the United Nations, internal conditions in Brunei were cleverly juggled by the colonialists who had considerable rubber, oil, and tin fortunes to lose. Indonesia has been duped and humiliated in the eyes of the whole world. This affront to my country is a personal hurt (Adams, 1965: 301).

Facing such insults, Sukarno became obsessed with humiliating and destroying Malaysia, which lead to further incursions and acts of sabotage committed by Indonesians in 1963-4. These actions made Malaysia to take the matter into Security Council on September 1964, and the Security Council passed a resolution against Indonesia that was vetoed by USSR.

This episode further confirmed Sukarno's dissatisfaction with the United Nations, which he believed as the agent of the "Old Established Forces," and he demanded the reformation of the UN. By 1965, his distaste toward the new Federation of Malaysia and Britain was so great that when the United Nations agreed to have Malaysia serve in the Security Council, Sukarno abruptly decided to pull Indonesia out of the United Nations, to the surprise of everyone including Indonesians themselves (Mackie, 1974: 283). 


\section{Testing the Three Hypothesis}

In testing this case against the neorealist's hypothesis, the case of Indonesia does not disprove neorealist's hypothesis that state will withdraw from international organization when the international organization no longer fit its interests. Indonesia had tried using the United Nations to advance its interests by forcing Malaysia to agree for a United Nations ascertainment mission, although to its chagrin the result was not according to what Indonesia expected. As Indonesia started to pursue a belligerent policy, the United Nations was no longer seen as accommodative Indonesia's interests. Furthermore, Indonesia saw that the admission of Malaysia as a member of Security Council as an insult to Indonesia that signaled a global acceptance to the formation of Malaysia, which Indonesia opposed. Since Indonesia found the United Nations no longer useful to its interests, then it decided to withdraw. However, since Indonesia was not a hegemonic state which withdrawal would cause the international regimes to collapse, there was not a significant impact on the United Nations itself.

The neoliberal/functionalists hypothesis was quite shaky in this case. Indonesia's withdrawal was to the contrary of Neoliberal/functionalist hypothesis that state would not withdraw from international regimes when it benefits from the existence of international regimes. Indonesia's withdrawal from the United Nations made it essentially a pariah in international relations. Worse, Indonesia lost many benefits that it could gain by staying in the United Nations such as United Nations' assistance programs to eradicate illiteracy and various other technical assistances (Mackie, 1974: 283).

The second part of neoliberal/functionalist hypothesis that a state will remain in international regime if it remains sharing common interests with the regime was also disproved. If we look at the common interests of the state and international organization functionally, such as the common interests of both state and regime to eradicate illiteracy, then Indonesia's self-withdrawal from 
the United Nations was a self-defeating move that completely against its interests. Therefore, neoliberal/functionalist hypothesis was unable to account Indonesia's withdrawal from the United Nations.

The constructivist hypothesis looks at the identity of Indonesia, whether Indonesia during that era of Konfrontasi shared a common identity with the United Nations, and in that sense it was correct that Indonesia under Sukarno no longer felt to share the same identity with the United Nations. By 1965 , Sukarno was convinced that the United Nations was simply unfixable and it was simply a tool of the neocolonialists and imperialists (Old Established Forces) to impose its order to the third world countries (the Newly Emerging Forces). Since he no longer shared the same identity, then the only recourse left for Sukarno was to take Indonesia out from the United Nations. As the result, the constructivists' hypothesis is not disproved.

Having discussed these approaches, then it seems that both neorealism and constructivism have the most plausible explanation toward why Indonesia withdraw from the United Nations. However, the explanation remains lacking, especially for neorealism, such as why the policy of "Konfrontasi" never exploded to a full-blown war or why Indonesia did not pursue this policy as vigorous as its previous adventure in West Irian. In addition, why Indonesia withdrew in 1965, instead of in 1963 when the result of the United Nations ascertainment mission did not satisfy Indonesiaes interest. Neorealist hypothesis was unable to answer this, as this decision was as a result of domestic policy influence.

\section{Neoclassical Realism: The Domestic Power Politics Model}

Since we have observe that neorealist's hypothesis has some supports in our case study, then we can take the hypothesis and work from the assumption that state's decision to withdrawal from international regimes depends on whether the international regimes can further its interests. The question is that where the state"s interest come from, and in this section will argue that the interest come from the interplay between the domestic interest groups and the 
leader who has to do the balancing act in order to maintain his or her control over the interest groups. This is the approach of neoclassical realism, which stresses the importance of domestic power politics that determines foreign policy choice that a state takes in facing the systemic constraints (Rose, 1998: 147).

In every state of the world, leaders have to have strong power base in order to be able to remain in power. In democratic countries, election is the common way for a leader to have a power base, so how strong the power base of a leader is depended on how much vote those leaders get. In non-democratic states however, the main sources of power are elite groups, and a leader who want to remain on the top need to become good arbiter, where he or she engages in balancing act in order to keep the power of elite groups equal in strength and in check. Should the power of a group starts to get too strong, then the leader must pursue a policy to put a check lest the interest group becomes too powerful and can dictate its will toward the leader and thus threaten his or her position. On the other hand, interest groups themselves have a balancing mechanism where they essentially try to balance the other groups from getting too strong and undercutting their influences in policy. Leader's main purpose is to keep these groups from engaging in aggressive balancing that can lead to conflict that could ultimately undercut the leader's power.

This behavior is translated to the foreign policy. Interest groups often use foreign policy as a way to exert its influences and as a signal to its rivals that it was in power. As the result, interest groups will compete to put its foreign policy into table, yet they will also make sure that the policy that they advocate do not put benefits other groups. On top of that, the leader is the main determinant whether the interest group's policy will be used and the leader also the one who determine how far he or she will pursue a foreign policy before he or she starts to put the policy in check in order to limit the interest group's influence. 
From these discussions then I put a combined hypothesis that national interest is derived from the "struggle of dominance" between dominant interest groups. Ultimately however, leaders are the ones who determine the extent to which a group's policy will be taken, and leaders' choices are depended on how far the leaders want to increase interest groups' power and influence in order to balance against other interest groups. On the other hand, leaders themselves are limited by political prestige, as any sign of weaknesses would throw into question the leaders' capacity as the arbiter of power.

In testing this model, we have to look at the domestic power struggle in Indonesia. After the formation of Guided Democracy, Sukarno, as the center of power in Indonesian politics, was engaging in a balancing act between the two most powerful political actors in Indonesian politics: the Army and PKI (Indonesian Communist Party). His main concerns however lied on the former, as the Army in 1962 had emerged as the most powerful actor due to two factors: (1) the martial law that Sukarno imposed since 1959 when he disbanded the parliament (Mackie, 1974: 82) and (2) the West Irian campaign that was waged in 1961-2 that increased the military budget and its success increased both Sukarno and military's prestige (Mackie, 1974: 99-101).

By the end of 1962 the West Irian campaign was essentially over, and Indonesia could focus on another diplomatic problem: the idea of Malaysia that was first advocated in 1961. In 1961, due to Indonesia's preoccupation with West Irian, Indonesia's reaction to Malaysia was muted. By the end of 1962 however, things started to change due to several important factors: (1) the visitation of North Kalimantan dissidents to Jakarta, whose cause was immediately taken by Indonesian Communist Party (PKI), seeing this as an opportunity to increase its prestige by stroking nationalistic and antiimperialistic fervor, (Mortimer, 1974: 204) (2) economic problems caused by mounting inflation and budgetary crisis due to the high cost of West Irian campaign that forced Indonesia to pursue stabilization, an unpopular belttightening economic measure, and (3) once PKI's anti-imperialists criticism started to gather steam and generate wide supports, it was necessary for 
Sukarno to finally address this issue (Mackie, 1974: 105). To further strengthen Sukarno's decision to involve in anti-Malaysian policy, the Brunei Revolt essentially caused Sukarno, who held grudges against Malaysia, to believe that it was possible to achieve a quick foreign policy victory that would divert publik's attention from the economic problem with no significant cost to Indonesia.

Jumping into Sukarno's anti-Malaysia bandwagon was the army. As discussed above, the Indonesian Communist Party was trying to increase its prestige and it also want to halt Indonesia's turn to pro-Western foreign policy orientation that was evident by Indonesia's acceptance on the economic stabilization program (Mortimer, 1974: 205). The army's main interests however were quite complex. While the army feared a cutback in their budget once the West Irian crisis was over, they were generally in favor for the economic stabilization scheme (Mackie, 1974: 132). Their fear, however, lied on the fact that PKI's sudden seizure of the Malaysian issue would leave them outflanked. In addition, the end of West Irian campaign could also mean that Sukarno would soon lift the martial law that would undercut their political power further (which he finally did in May 1963 that caused the military to lose significant amount of influence in civil affairs) (Mackie, 1974: 134). Facing these dilemmas, the military decided to support Sukarno's antiMalaysian campaign.

Once the nationalistic fervor was unleashed, none of these political actors could withdraw lest they find their political power undercut. This was especially true when the United Nations ascertainment mission was producing unfavorable result from Indonesia and Malaysia's announcement by the end of August that it would go ahead with the creation of the Malaysian Federation regardless what the result from the ascertainment mission on September 16, 1963 that essentially means a slap on Sukarno's face (Mackie, 1974: 174). On September 15, Indonesia refused to accept the UN report and decided to 
withhold the recognition of Malaysia, which resulted in Malaysia's decision to severe diplomatic relationship on September 17. On September 16, the situation further escalated when Indonesian mob attacked the British embassy in Jakarta, and the next day, Malayan mob burned Indonesian embassy in Kuala Lumpur and Indonesian media reported that Malaysia's prime minister was stamping Indonesia's national emblem that culminated in the burning of the British embassy in Jakarta on September 18 followed by the destruction of every British-owned house in Jakarta (Mackie, 1974: 187).

For all these mess happened in Jakarta and Kuala Lumpur, surprisingly the actual military dispute between Malaysia and Indonesia remain limited to border incursions. The reason was that both the army and PKI were unwilling to push for open conflict. PKI feared that the increase in intensity of the Malaysian campaign would mean re-imposition of martial law that would benefit the army (Mackie, 1974:242). The army however simply did not believe that the campaign would be successful and they simply would not risk a British counterattack that would essentially demoralize the army (Mackie, 1974: 263). Sukarno on the other hand was trying to end the conflict using combination of both threats and compromises toward Malaysia in 1963-5. Yet Malaysia and the British simply refused to provide him a face-saving exit that forced him to embroil further into the Konfrontasi (Legge, 1984: 37). International events also worked against him, such as Indonesia's defeat in the Security Council that was discussed above. Finally, Malaysia's admittance as a member of Security Council in 1965 was simply too much insult for Sukarno to bear and he decided to withdraw from the United Nations.

From this second case then we can see that the domestic balancing was a very important factor in determining the conduct of foreign policy. PKI and the army's political struggles essentially limited Konfrontasi from becoming a full-blown war. On the other hand, Sukarno as a leader was in bind, as his involvement in Malaysia was the product of domestic struggle, yet to extricate 
himself from this conflict that started to get out of his control was simply impossible due to the amount of political capital involved and not to mention that his withdrawal from the conflict would mean the acceptance of defeat and brought his capacity of the arbiter of power into question. He was seeking a face-saving formula, which was denied from him by both the British and the Malaysian, that lead to further intensification of the conflict.

\section{Conclusion}

In trying to make sense about Indonesia's withdrawal from the United Nations, the neo-classical realist model has the best explanatory ability. Domestic political struggle influences the conduct of foreign policy of a state. Indonesia's decision to withdraw from the United Nations was basically a combination of both international and domestic factors: internationally, the United Nations was seen as no longer conductive toward national interests, while domestically, Indonesia's domestic pressure in 1964-5 was too strong to be ignored by the decision-makers.

\section{Bibliography}

\section{Articles}

"Britain and the EU: A tragic split," The Economist (June 24, 2016) https://www.economist.com/news/leaders/21701265-how-minimisedamage-britains-senseless-self-inflicted-blow-tragic-split

Macshane, Denis, "Brexit no longer as unthinkable as it once was," Business Report (May-11-2015) https: / /www.iol.co.za/business -report/ opinion/brexit-no-longer-as-unthinkable-as-it-once-was-1856471

Morgenthau, Hans J., "The UN in Crisis," The New York Review of Books (March 25, 1965) http://www.nybooks.com/articles/1965/03/25/the-unin-crisis/

Totaro, Paola, "A Brexit is unthinkable, but not impossible with Boris on side," ABCNews (February 25, 2016) http://www.abc.net.au/news/2016-0225/totaro-brexit-is-unthinkable,-but-not-impossible-with-boris/7198222 


\section{Journal Articles}

Finnemore, Martha, "International Organizations as Teachers of Norm," International Organization 47, 4 (Autumn 1993)

Hopf, Ted, "The Promise of Constructivism in International Relations Theory," In International Security 23:1 (Summer 1998)

Krasner, Stephen D., "State Power and the Structure of International Trade," World Politics, 28, 3 (April 1976)

Rose, Gideon, "Review: Neoclassical Realism and Theories of Foreign Policy," World Politics, Vol. 51, No. 1 (Oct 1998)

\section{Books}

Adams, Cindy, Soekarno: An Autobiography As Told to Cindy Adams (Indianapolis: the Bobbs-Merrill Company, Inc., 1965)

Jones, Howard Palfrey, Indonesia: the Possible Dream (New York: Harcourt Brace Jovanovich, Inc., 1971)

Jones, Matthew, Conflict and Confrontation in South East Asia 1961-1965 (Cambridge: Cambridge University Press, 2002)

Keohane, Robert O., After Hegemony (Princeton: Princeton University Press, 1984) 244-5.

Mackie, J.A.C., Konfrontasi: The Indonesia-Malaysia Dispute 1963-1966 (Kuala Lumpur: Oxford University Press, 1974)

Mortimer, Rex, Indonesian Communism Under Sukarno: Ideology and Politics 1959-1965 (Ithaca: Cornell University Press, 1974)

Legge, J.D., Sukarno: A Political Biography (Sydney: Allen \& Unwin, 1984)

Subritzky, John, Confronting Sukarno: British, American, Australian and New Zealand Diplomacy in the Malaysian-Indonesian Confrontation, 1961-5 (New York: St. Martin's Press, Inc., 2000)

\section{Book Chapters}

Grieco, Joseph M., "Anarchy and the Limits of Cooperation" In David Allen Baldwin, Neorealism and Neoliberalism (New York: Columbia University Press, 1993)

Jervis, Robert, "Security Regimes," In Stephen D. Krasner, International Regimes (Ithaca: Cornell University Press, 1983)

Mearsheimer, John ,"Back to the Future: Instability in Europe after the Cold War" In Michael E. Brown et al, Theories of War and Peace (Cambridge: MIT Press, 2000)

-----, "False Promise of International Institutions" In Michael E. Brown et al, Theories of War and Peace (Cambridge: MIT Press, 2000)

Shanks et al, "Inertia and Change in the Constellation of International Governmental Organizations, 1981-1992" In Lisa Martin and Beth Simmons, International Institutions (Cambridge: MIT Press, 2001) 